\title{
A Research on the Comparative Effect of Active Dry Yeast and Inactivated- Stabilized Probiotic Yeast (Thepax) Added at Different Levels to Diets on Broiler Performance
}

\author{
Süleyman Çalışlar ${ }^{1, a, *}$, Rahmi Kanat ${ }^{2, b}$ \\ ${ }^{1}$ Department of Animal Science, Faculty of Agriculture, Kahramanmaraş Sütçü Imam University, 46050 Kahramanmaraş, Turkey \\ ${ }^{2}$ Department of Animal Science, Faculty of Agriculture, Harran University, 63050 Şanliurfa, Turkey \\ *Corresponding author \\ A R T I C L I N F O A B S T R A C T \\ Research Article \\ This experiment was conducted to determine the effect of active yeast (AY) and inactive-stabilized \\ yeast (Thepax) supplementation to the rations in different levels on broiler performance. In the \\ experiment carried out according to the randomized plot design, there were 5 different treatment \\ groups as control group (Group 1), 0.1\% Thepax (Group 2), 0.2\% Thepax (Group 3), 0.1\% AY \\ Received : 01/06/2021 \\ Accepted : 14/12/2021 \\ (Group 4) and 0.2\% AY (Group 5). In the experiment, the effects of active and inactive yeasts on \\ body weight gain (BWG), feed consumption, feed conversion rate, carcass weight (CW), carcass \\ yield (CY), abdominal fat amount and mortality were investigated. In the present experiment, the \\ final live weight, the cumulative feed consumption and feed conversion were insignificant. The \\ statistical difference between the groups in the experiment was significant in carcass weight, but \\ insignificant in the amount of abdominal fat and mortality rate. Inactive-stabilized yeast (Thepax \\ $0.1 \%$ ) was more effective than $0.2 \%$ AY on BWG. Only $0.1 \%$ Thepax increased the CW besides \\ Keywords: \\ Broiler \\ CY was high in $0.1 \%, 0.2 \%$ Thepax and $0.1 \%$ AY groups. It has been observed that active and \\ Performance \\ Active dried yeast \\ Probiotic yeast \\ inactive yeasts are used in broiler chickens without any problem. \\ Feed conversion

\section{Introduction}

Growth promoters and some antibiotics have been used for many years in order to obtain higher yields from animals. However, in recent years, the use of some antibiotics in animal nutrition has been banned due to the adverse effects on the health of people who consume such animal products (Salim et al., 2018). Studies on finding alternative and natural resources to replace these banned products have intensified.

Feeding with high protein and energy-containing feeds adversely affects the stability of the intestinal microflora of poultry, and especially the chicks become much more susceptible to pathogenic organisms. In such cases, the use of probiotic products ensures the stabilization of the intestinal microflora ecosystem and prevents the development of pathogenic microorganisms (Thongsong et al., 2008).

It is thought that yeasts, which are produced from beneficial microorganisms by biotechnological methods and also known as single cell proteins, can promote growth and be an alternative to some antibiotics (Gong et al., 2002;
Fathi et al., 2012). Therefore, products containing yeast and yeast, which have both prebiotic and probiotic effects, have recently begun to be preferred in poultry feeding.

Dry yeast is a rich source of protein and contains $47 \%$ crude protein, $33 \%$ carbohydrate, $8 \%$ mineral, $8 \%$ nucleic acid and $4 \%$ lipid. Also, yeast is a very good source of $B$ complex vitamins. However, it is poor in vitamins A, D, and C (Reed and Tilak, 1991; Reed, 2012).

Live yeast cultures provide digestion of food since they contain digestive enzymes such as amylase, maltase, sucrose, lactate dehydrogenase, proteinase, polypeptides, dipeptidase, deaminase, transaminase, lipase, phospholipase, phosphatase and phytase (Stanley et al., 1993). Without the enzymes contained in yeast, sugars cannot be fermented to form fermentation products such as carbon dioxide and ethyl alcohol (Elgün and Ertugay, 1990). Yeasts with probiotic effects affect growth positively by inhibiting harmful bacteria in the intestinal mucosa (Hassanein and Soliman, 2010). 
Yeast culture is a nutrient-rich and complex microecological fermentation product containing a variety of metabolites. Glycine, fructose, inositol, galactose and sucrose are potentially effective main metabolites obtained from yeast culture as a result of fermentation. However, the specific effective components of yeast culture and their importance in poultry nutrition are not fully known (Sun et al., 2019).

Because the yeast added to the food provides an environment that prevents the development of pathogenic microflora in poultry (Ogbuewu et al., 2019), the production of digestive enzymes, the provision of immunity (Wang et al., 2017) and the detoxification of pathogen toxins (Martinez et al., 2004) has been found to have a positive effect on the yield performance of broilers (Santin et al., 2001).

The yeast added to the feed had a positive effect on the growth performance and body weight gain of 6-week-old chickens (Suzer et al., 2015). The addition of yeast to the feed reduced the amount of abdominal fat in broilers (Afsharmanesh et al., 2010). Saccharomyces cerevisiae has a positive effect on meat quality and carcass characteristics in broilers (Gao et al., 2008).

Yeast cells are generally in spiral, oval or cylindrical shapes (Brock et al., 1984) and can operate within a wide $\mathrm{pH}$ range (3-7.5) (Köşker and Çakmakçı, 1985). Live Saccharomyces cerevisiae cells usually break down and degrade in a hot or even warm environment. Since inactivated-stable yeast is protected due to inactivation and stabilization processes, it is not affected by antibiotics, temperature and gastric acid. Containing nucleotides, amino acids and vitamins, inactivated-stable yeast encourages the growth of beneficial microorganisms, especially lactobacilli, allowing them to discharge their bioactive content into the intestinal area. Therefore, inactivated-stable yeast has a direct effect on the animal's metabolism in terms of accelerating morphological development and stimulating growth (Anonymous, 1983).

Inactivated-stable yeast is a completely natural probiotic based product produced by inactivating and stabilizing selected ellipsoidal strains of Saccharomyces cerevisiae with a patented technology (Rose and Harrison, 1971). These commercially produced yeasts are used in many areas such as food, beverage, medicine, industrial enzyme production and animal feeding (Vohra et al., 2016).

In this study, the effects of active-dry baker's yeast (AY) added to the ration at different levels and natural active-stable based yeast on the yield performance of broiler chickens were investigated comparatively.

\section{Materials and Methods}

\section{Animal}

A total of 300 broiler chicks (Avian) used as trial material were obtained from the private sector. The chicks were randomly distributed by weighing them into the trial sections prepared at the end of the first week.

\section{Feed}

The active dry yeast added to the experimental rations was obtained from the market and Thepax from a commercial company (Doxal Co., Italy). Chemical compositions of inactive-stabilized yeast and AY used in this study are given (Table 1).

The formulation of the different rations used in the experiment was pre-calculated to be isonitrogenic and isocaloric, and trial rations were produced in a commercial feed factory in accordance with these calculations (Table 2 and Table 3; NRC, 1994).

\section{Trial Design and Treatment Groups}

The trial was designed according to the coincidence plot pattern. In the experiment, chicks were fed with adaptation feed collectively in the first week. At the beginning of the 2 nd week, the trial chicks, which were weighed on a sensitive scale, were placed in trial chambers made of wooden material. Chicks 8-21. 1st period feed (broiler chick) was given between days and 2 nd period feed (broiler chick) between 22-49 days. Feed and water were given to the chicks ad-libitum.

Table 1. Chemical composition of Thepax and active dry baker's yeast

\begin{tabular}{|c|c|c|c|c|c|}
\hline \multicolumn{4}{|c|}{ Thepax's nutritional content (Anonyomus, 1983) } & \multicolumn{2}{|c|}{ Nutritional content of active dry baker's yeast** } \\
\hline Nutrients & $\%$ & Nutrients & $\%$ & Nutrients & $\%$ \\
\hline Dry matter & 92.0 & Histidine & 0.64 & Dry matter & 91.24 \\
\hline Protein & 28.9 & Lysine & 1.39 & Protein & 46.18 \\
\hline Cellulose & 8.13 & Leucine & 1.66 & Fat & 0.77 \\
\hline Fat & 2.57 & Methionine & 0.41 & Cellulose & 0.37 \\
\hline Ash & 7.80 & Phenylalanine & 0.93 & Ash & 4.64 \\
\hline $\mathrm{P}_{2} \mathrm{O}_{5}$ & 3.60 & Threonine & 1.06 & NFE & 39.28 \\
\hline $\mathrm{Na}_{2} \mathrm{O}$ & 0.50 & Tryptophan & 0.22 & Calcium & 0.23 \\
\hline $\mathrm{MgO}$ & 0.90 & Tyrosine & 0.88 & Phosphorus & 1.02 \\
\hline $\mathrm{CaO}$ & 0.23 & Valine & 1.21 & ME (kcal / kg) & 2600 \\
\hline $\mathrm{SO}_{3}$ & 0.57 & Vitamin B1 & 13.2 & - & - \\
\hline $\mathrm{FeO}$ & 0.71 & Vitamin B2 & 43.4 & - & - \\
\hline Glutamic acid & 1.11 & Inositol & 1330 & - & - \\
\hline Arginine & 1.02 & Biotin & 0.00 & - & - \\
\hline Cystine & 0.39 & Pantothenic acid & 0.84 & - & - \\
\hline Isoleucine & 1.10 & Nicotinic acid & 210 & - & - \\
\hline \multicolumn{3}{|c|}{ Minimum final concentration } & $\begin{array}{c}12.000 .000 .000 \\
\text { cell/gram }\end{array}$ & $\begin{array}{l}* \text { Minimum final } \\
\text { concentration }\end{array}$ & $\begin{array}{c}11.600 .000 .000 \\
\text { cell/gram }\end{array}$ \\
\hline
\end{tabular}

$\mathrm{P}_{2} \mathrm{O}_{5}$ : Phosphorus pentaoxide. $\mathrm{Na}_{2} \mathrm{O}=$ Sodium oxide. $\mathrm{MgO}=$ Magnesium oxide. $\mathrm{CaO}=$ Calcium oxide. $\mathrm{SO}_{3}=\mathrm{Sulfur}$ trioxide. FeO= Iron oxide. $\mathrm{ME}$ : Metabolic Energy. NFE: Nitrogen-free extracts. * Minimum final concentration (analyzed) contained in each gram of yeast, **(Yalçın et al., 1993). 
Table 2. The rations used in the first period of the trial (7-21 days) and their composition $(\mathrm{g} / \mathrm{kg})$

\begin{tabular}{|c|c|c|c|c|c|}
\hline Ingredients & $\begin{array}{l}\text { Control } \\
\text { (Group 1) } \\
\end{array}$ & $\begin{array}{c}0.1 \% \text { Thepax } \\
\text { (Group 2) }\end{array}$ & $\begin{array}{c}0.2 \% \text { Thepax } \\
\text { (Group 3) }\end{array}$ & $\begin{array}{l}0.1 \% \text { AY } \\
\text { (Group 4) }\end{array}$ & $\begin{array}{l}0.2 \% \text { AY } \\
\text { (Group 5) }\end{array}$ \\
\hline Corn & 314.6 & 313.6 & 312.6 & 313.6 & 312.6 \\
\hline Soybean meal (\% 44.5) & 260.0 & 260.0 & 260.0 & 260.0 & 260.0 \\
\hline Wheat & 250.0 & 250.0 & 250.0 & 250.0 & 250.0 \\
\hline Meat-bone meal & 78.0 & 78.0 & 78.0 & 78.0 & 78.0 \\
\hline Fish meal & 42.0 & 42.0 & 42.0 & 42.0 & 42.0 \\
\hline Sunflower acid oil & 24.0 & 24.0 & 24.0 & 24.0 & 24.0 \\
\hline Crude soy oil & 22.0 & 22.0 & 22.0 & 22.0 & 22.0 \\
\hline Inactive-stabile yeast (Thepax) & 0.00 & 1.00 & 2.00 & 0.00 & 0.00 \\
\hline Active dried yeast (AY) & 0.00 & 0.00 & 0.00 & 1.00 & 2.00 \\
\hline Methionine & 2.00 & 2.00 & 2.00 & 2.00 & 2.00 \\
\hline Lysine & 0.40 & 0.40 & 0.40 & 0.40 & 0.40 \\
\hline Sodium cloride & 2.50 & 2.50 & 2.50 & 2.50 & 2.50 \\
\hline Vitamin premix & 2.00 & 2.00 & 2.00 & 2.00 & 2.00 \\
\hline Mineral premix & 1.50 & 1.50 & 1.50 & 1.50 & 1.50 \\
\hline Anticoccidial & 1.00 & 1.00 & 1.00 & 1.00 & 1.00 \\
\hline Total $(\mathrm{kg})$ & 1000 & 1000 & 1000 & 1000 & 1000 \\
\hline Nutrients, $\%$ & \multicolumn{5}{|c|}{ Calculated nutrient composition } \\
\hline Dry matter & 92.99 & 92.99 & 92.99 & 92.99 & 92.99 \\
\hline Crude protein & 22.65 & 22.65 & 22.65 & 22.65 & 22.65 \\
\hline Metabolic energy, $\mathrm{kcal} / \mathrm{kg}$ & 3060 & 3060 & 3060 & 3060 & 3060 \\
\hline Crude cellulose & 3.19 & 3.19 & 3.19 & 3.19 & 3.19 \\
\hline Crude ash & 5.81 & 5.81 & 5.81 & 5.81 & 5.81 \\
\hline Crude fat & 8.80 & 8.80 & 8.80 & 8.80 & 8.80 \\
\hline Calcium & 1.20 & 1.20 & 1.20 & 1.20 & 1.20 \\
\hline Phosphorus & 0.62 & 0.62 & 0.62 & 0.62 & 0.62 \\
\hline
\end{tabular}

2 kg vitamin content: Vitamin A 15000000 IU. Vitamin D3 1500000 IU. Vitamin E 40000 mg. Vitamin K3 5000 IU. Vitamin B1 300 0mg. Vitamin B2 $7000 \mathrm{mg}$. Vitamin B6 $5000 \mathrm{mg}$. Vitamin B12 $20 \mathrm{mg}$. Vitamin C $50000 \mathrm{mg}$. D-Biotin $70 \mathrm{mg}$. Niacin $25000 \mathrm{mg}$. Calcium D Pantothenate $10000 \mathrm{mg}$. Folic Acid $750 \mathrm{mg}$. Choline Chloride $200000 \mathrm{mg}$. Ascorbic acid $15000 \mathrm{mg} .1 .5 \mathrm{~kg}$ mineral content: Manganese $80000 \mathrm{mg}$. Iron $60000 \mathrm{mg}$. Zinc 60000 mg. Copper $5000 \mathrm{mg}$. Iodine $1000 \mathrm{mg}$. Cobalt $200 \mathrm{mg}$. Selenium $150 \mathrm{mg}$. Calcium $446925 \mathrm{mg}$.

Table 3. The rations used in the second period of the trial (22-49 days) and their composition $(\mathrm{g} / \mathrm{kg})$

\begin{tabular}{|c|c|c|c|c|c|}
\hline Ingredients & $\begin{array}{c}\text { Control } \\
\text { (Group 1) } \\
\end{array}$ & $\begin{array}{c}\text { 0.1\% Thepax } \\
\text { (Group 2) }\end{array}$ & $\begin{array}{c}0.2 \% \text { Thepax } \\
\text { (Group 3) }\end{array}$ & $\begin{array}{l}0.1 \% \text { AY } \\
\text { (Group 4) }\end{array}$ & $\begin{array}{l}0.2 \% \text { AY } \\
\text { (Group5) }\end{array}$ \\
\hline Corn & 316.0 & 315.0 & 314.0 & 315.0 & 314.0 \\
\hline Soybean meal (\% 44.5) & 250.0 & 250.0 & 250.0 & 250.0 & 250.0 \\
\hline Wheat & 250.0 & 250.0 & 250.0 & 250.0 & 250.0 \\
\hline Meat-bone meal & 80.0 & 80.0 & 80.0 & 80.0 & 80.0 \\
\hline Fish meal & 32.0 & 32.0 & 32.0 & 32.0 & 32.0 \\
\hline Sunflower acid oil & 32.0 & 32.0 & 32.0 & 32.0 & 32.0 \\
\hline Crude soy oil & 31.0 & 31.0 & 31.0 & 31.0 & 31.0 \\
\hline Inactive-stabile yeast (Thepax) & 0.00 & 1.00 & 2.00 & 0.00 & 0.00 \\
\hline Active dried yeast (AY) & 0.00 & 0.00 & 0.00 & 1.00 & 2.00 \\
\hline Methionine & 1.90 & 1.90 & 1.90 & 1.90 & 1.90 \\
\hline Lysine & 0.10 & 0.10 & 0.10 & 0.10 & 0.10 \\
\hline Sodium cloride & 2.50 & 2.50 & 2.50 & 2.50 & 2.50 \\
\hline Vitamin premix & 2.00 & 2.00 & 2.00 & 2.00 & 2.00 \\
\hline Mineral premix & 1.50 & 1.50 & 1.50 & 1.50 & 1.50 \\
\hline Anticoccidial & 1.00 & 1.00 & 1.00 & 1.00 & 1.00 \\
\hline Total $(\mathrm{kg})$ & 1000 & 1000 & 1000 & 1000 & 1000 \\
\hline Nutrients, $\%$ & \multicolumn{5}{|c|}{ Calculated nutrient composition } \\
\hline Dry matter & 92.99 & 92.99 & 92.99 & 92.99 & 92.99 \\
\hline Crude protein & 21.62 & 21.62 & 21.62 & 21.62 & 21.62 \\
\hline Metabolic energy, $\mathrm{kcal} / \mathrm{kg}$ & 3158 & 3158 & 3158 & 3158 & 3158 \\
\hline Crude cellulose & 3.14 & 3.14 & 3.14 & 3.14 & 3.14 \\
\hline Crude ash & 6.33 & 6.33 & 6.33 & 6.33 & 6.33 \\
\hline Crude fat & 9.76 & 9.76 & 9.76 & 9.76 & 9.76 \\
\hline Calcium & 1.39 & 1.39 & 1.39 & 1.39 & 1.39 \\
\hline Phosphorus & 0.60 & 0.60 & 0.60 & 0.60 & 0.60 \\
\hline
\end{tabular}

2 kg vitamin content: Vitamin A 15000000 IU. Vitamin D3 1500000 IU. Vitamin E $40000 \mathrm{mg}$. Vitamin K3 5000 IU. Vitamin B1 300 0mg. Vitamin B2 $7000 \mathrm{mg}$. Vitamin B6 $5000 \mathrm{mg}$. Vitamin B12 $20 \mathrm{mg}$. Vitamin C $50000 \mathrm{mg}$. D-Biotin $70 \mathrm{mg}$. Niacin $25000 \mathrm{mg}$. Calcium D Pantothenate $10000 \mathrm{mg}$. Folic Acid $750 \mathrm{mg}$. Choline Chloride $200000 \mathrm{mg}$. Ascorbic acid $15000 \mathrm{mg}$. $1.5 \mathrm{~kg}$ mineral content: Manganese $80000 \mathrm{mg}$. Iron $60000 \mathrm{mg}$. Zinc 60000 mg. Copper $5000 \mathrm{mg}$. Iodine $1000 \mathrm{mg}$. Cobalt $200 \mathrm{mg}$. Selenium $150 \mathrm{mg}$. Calcium $446925 \mathrm{mg}$. 
Active dry and inactive-stable yeast (Thepax) was added to the experimental rations at the rates of $0,0.1$, and $0.2 \%$. Accordingly, in the study, mainly the control group (Group 1), 0.1\% Thepax (Group 2) and 0.2\% Thepax (Group 3), $0.1 \%$ AY (Group 4) and 0.2\% AY (Group). There were 5 different treatment groups. Each treatment group consisted of 3 replications and the study was conducted with a total of 300 chicks, with 20 birds in each repetition.

\section{Determination of Trial Data}

The chicks in the experiment were weighed routinely at the end of each week and their body weight and performance data were recorded regularly. Since adaptation feeding was applied, the first week weights were accepted as the starting weight of the trial and accordingly, the other weightings were determined weekly.

In the study, the amount of feed consumed by the experimental chickens was determined on the basis of the repetition groups since the group feeding was done. The determined feed amounts were divided by the number of animals present in each repetition and the feed amounts of each treatment group were recorded weekly.

Slaughter weight, carcass, yield and abdominal fat amount were determined in the experimental chickens that were slaughtered. For this, 5 chickens closest to the average live weight from each repetition of the groups were selected and the slaughter and carcass data of these selected chickens were determined. Accordingly, a total of 15 broilers from each group were used. The belly fat of the chickens was determined by taking the fat layer around the abdomen, cloaca and gizzard (Kubena et al., 1974).

\section{Statistical Analysis}

The statistical package program was used for statistical analysis of the data obtained in the experiment. The data were evaluated according to Duncan test.

\section{Results}

In this study, weekly results of feed consumption, body weight, body weight gain and feed conversion ratio values throughout the trial (2-7 weeks) are given in Table 4.

The effects of treatments on feed conversion rates at the third week of age and on feed intake at the seventh week of age were found to be significant $(\mathrm{P}<0.05$; Table 4$)$. The effects of the treatments on IBW, FLW, BWG, FI and FCR in weeks other than this (second, fourth, fifth and sixth) were insignificant.

Table 4. The effect of feeding with rations containing Thepax and active yeast on some yield parameters of broilers

\begin{tabular}{|c|c|c|c|c|c|c|}
\hline \multirow[b]{2}{*}{ Parameters } & \multicolumn{6}{|c|}{ Treatment groups $(8-14 \mathrm{~d})$} \\
\hline & $\begin{array}{c}\text { Control } \\
\text { (Group 1) }\end{array}$ & $\begin{array}{l}0.1 \% \text { Thepax } \\
\text { (Group 2) }\end{array}$ & $\begin{array}{c}\text { 0.2\% Thepax } \\
\text { (Group 3) }\end{array}$ & $\begin{array}{l}0.1 \% \text { AY } \\
\text { (Group 4) }\end{array}$ & $\begin{array}{l}0.2 \% \text { AY } \\
\text { (Group 5) }\end{array}$ & $\begin{array}{c}\mathrm{P} \\
\text { value }\end{array}$ \\
\hline IBW & 146.96 & 133.83 & 136.50 & 147.83 & 142.23 & NS \\
\hline BW & 320.96 & 313.66 & 324.30 & 346.83 & 315.73 & NS \\
\hline BWG & 174.00 & 179.83 & 187.80 & 199.00 & 173.50 & NS \\
\hline FI & 273.43 & 268.60 & 270.63 & 291.66 & 277.00 & NS \\
\hline \multirow[t]{2}{*}{ FCR } & 1.57 & 1.49 & 1.45 & 1.46 & 1.60 & NS \\
\hline & \multicolumn{6}{|c|}{$15-21 \mathrm{~d}$} \\
\hline BW & 710.36 & 679.13 & 666.46 & 703.00 & 677.10 & NS \\
\hline BWG & 389.40 & 365.46 & 324.16 & 356.16 & 361.36 & NS \\
\hline FI & 539.00 & 524.33 & 532.93 & 502.16 & 517.13 & NS \\
\hline \multirow[t]{2}{*}{ FCR } & $1.39 \mathrm{~b}$ & $1.43 \mathrm{ab}$ & $1.65 \mathrm{a}$ & $1.40 \mathrm{~b}$ & $1.43 \mathrm{~b}$ & 0.05 \\
\hline & \multicolumn{6}{|c|}{$22-28 d$} \\
\hline BW, g & 1115.53 & 1088.06 & 1075.23 & 1087.00 & 1064.93 & NS \\
\hline BWG, g & 405.17 & 408.93 & 408.77 & 384.00 & 387.83 & NS \\
\hline FI, g & 639.10 & 649.83 & 673.56 & 643.83 & 651.00 & NS \\
\hline \multirow{2}{*}{ FCR, g/g } & 1.58 & 1.58 & 1.65 & 1.67 & 1.67 & NS \\
\hline & \multicolumn{6}{|c|}{$29-35 \mathrm{~d}$} \\
\hline $\mathrm{BW}, \mathrm{g}$ & 1550.43 & 1536.73 & 1485.20 & 1482.56 & 1464.83 & $\mathrm{NS}$ \\
\hline BWG, g & 434.90 & 448.73 & 409.97 & 395.56 & 399.90 & NS \\
\hline FI, g & 821.50 & 814.76 & 770.66 & 813.40 & 805.26 & NS \\
\hline \multirow[t]{2}{*}{ FCR, $g$} & 1.89 & 1.82 & 1.88 & 2.06 & 2.01 & NS \\
\hline & \multicolumn{6}{|c|}{$36-42 \mathrm{~d}$} \\
\hline $\mathrm{BW}, \mathrm{g}$ & 1884.10 & 1883.66 & 1794.73 & 1826.63 & 1737.36 & NS \\
\hline BWG, g & 333.67 & 349.93 & 309.53 & 344.06 & 272.532 & NS \\
\hline FI, g & 867.60 & 944.70 & 867.26 & 883.03 & 854.23 & NS \\
\hline \multirow[t]{2}{*}{ FCR, g/g } & 2.60 & 2.70 & 2.80 & 2.56 & 3.14 & NS \\
\hline & \multicolumn{6}{|c|}{$43-49 d$} \\
\hline $\mathrm{BW}, \mathrm{g}$ & 2237.23 & 2291.00 & 2180.26 & 2214.63 & 2075.33 & $\mathrm{NS}$ \\
\hline BWG, g & 353.13 & 407.33 & 385.53 & 388.00 & 337.96 & NS \\
\hline FI, g & $823.40 \mathrm{~b}$ & $920.53 a$ & $840.56 \mathrm{ab}$ & $818.80 \mathrm{~b}$ & $792.66 b$ & 0.05 \\
\hline FCR, g/g & 2.33 & 2.26 & 2.18 & 2.12 & 2.35 & NS \\
\hline
\end{tabular}

AY: Active yeast. IBW: Initial body weight. BW: Body weight. BWG= Body weight gain. FI= Feed intake. FCR= Feed conversion ratio. P= Probability. NS: None significant., ${ }^{a, b}$ Means within a column with no common superscripts differ significantly. 
Table 5- The effects of feeding with diets containing inactive and active yeast on general performance results of broiler chickens $(n=60)$

\begin{tabular}{|c|c|c|c|c|c|c|}
\hline \multirow[b]{2}{*}{ Parameters } & \multicolumn{6}{|c|}{ Treatment groups $(8-49 \mathrm{~d})$} \\
\hline & $\begin{array}{c}\text { Control } \\
\text { (Group 1) }\end{array}$ & $\begin{array}{c}0.1 \% \text { Thepax } \\
\text { (Group 2) }\end{array}$ & $\begin{array}{c}\text { 0.2\% Thepax } \\
\text { (Group 3) }\end{array}$ & $\begin{array}{l}0.1 \% \text { AY } \\
\text { (Group 4) }\end{array}$ & $\begin{array}{l}0.2 \% \text { AY } \\
\text { (Group 5) }\end{array}$ & $\begin{array}{c}\mathrm{P} \\
\text { value }\end{array}$ \\
\hline IBW, $\mathrm{g}$ & 146.96 & 133.83 & 136.50 & 147.83 & 142.23 & NS \\
\hline$\sum \mathrm{FBW}, \mathrm{g}$ & 2237.23 & 2291.00 & 2180.26 & 2214.63 & 2075.33 & NS \\
\hline$\sum \mathrm{BWG}, \mathrm{g}$ & $2090.26^{\mathrm{ab}}$ & $2157.23^{\mathrm{a}}$ & $2043.80^{\mathrm{ab}}$ & $2066.80^{\mathrm{ab}}$ & $1933.10^{\mathrm{b}}$ & 0.05 \\
\hline$\sum \mathrm{FI}, \mathrm{g}$ & 3963.90 & 4122.76 & 3955.56 & 3952.90 & 3897.30 & NS \\
\hline$\sum F C R, g / g$ & 1.89 & 1.91 & 1.93 & 1.91 & 2.01 & NS \\
\hline Mortality & 0.046 & 0.097 & 0.033 & 0.033 & 0.067 & NS \\
\hline
\end{tabular}

$\mathrm{IBW}=$ Initial body weight. $\sum \mathrm{FBW}=$ Final body weight. $\sum \mathrm{BWG}=$ Body weight gain. $\sum \mathrm{FI}=$ Feed intake. $\sum \mathrm{FCR}=\mathrm{Feed}$ conversion ratio. $\mathrm{P}=$ Probability. NS: None significant, ${ }^{\text {a,b }}$ Means within a column with no common superscripts differ significantly.

Table 6. The effects of feeding with diets containing inactive and active yeast on the results of slaughter and carcass parameters of broiler chickens $(n=15)$

\begin{tabular}{|c|c|c|c|c|c|c|}
\hline \multirow[b]{2}{*}{ Parameters } & \multicolumn{6}{|c|}{ Treatment groups $(8-49 \mathrm{~d})$} \\
\hline & $\begin{array}{l}\text { Control } \\
\text { (Group 1) }\end{array}$ & $\begin{array}{c}\text { 0.1\% Thepax } \\
\text { (Group 2) }\end{array}$ & $\begin{array}{c}\text { 0.2\% Thepax } \\
\text { (Group 3) }\end{array}$ & $\begin{array}{l}0.1 \% \text { AY } \\
\text { (Group 4) }\end{array}$ & $\begin{array}{l}0.2 \% \text { AY } \\
\text { (Group 5) }\end{array}$ & $\begin{array}{c}\mathrm{P} \\
\text { value }\end{array}$ \\
\hline SW, g & 2277.46 & 2327.33 & 2273.73 & 2262.73 & 2276.22 & NS \\
\hline $\mathrm{CW}, \mathrm{g}$ & $1629.33^{b}$ & $1710.00^{\mathrm{a}}$ & $1664.00^{\mathrm{b}}$ & $1660.80^{\mathrm{b}}$ & $1633.57^{b}$ & 0.05 \\
\hline $\mathrm{CY}, \%$ & $71.5^{\mathrm{b}}$ & $73.4^{\mathrm{a}}$ & $73.2^{\mathrm{a}}$ & $73.4^{\mathrm{a}}$ & $71.7^{\mathrm{b}}$ & 0.01 \\
\hline $\mathrm{ABF}, \mathrm{g}$ & 16.36 & 14.80 & 12.52 & 16.24 & 16.11 & NS \\
\hline
\end{tabular}

$\mathrm{SW}=$ Slaughter weight. $\mathrm{CW}=$ Carcass weight. $\mathrm{CY}=$ Carcass yield. $\mathrm{ABF}=$ Abdominal fat, ${ }^{\mathrm{a}, \mathrm{b}}$ Means within a column with no common superscripts differ significantly.

\section{General Performance Results}

In this study, the general results of the total feed consumption, total live weight gain and total feed utilization values of the trial are given in Table 5 . According to these general performance data, the effects of the treatments on the initial live weight, final live weight, feed consumption, feed conversion and mortality rates in broiler chickens were insignificant $(\mathrm{P}>0.05)$, but the effect on total body weight gain was found significant $(\mathrm{P}<0.05)$. The highest weight gain was $2157.23 \mathrm{~g}$ in group 2 (Thepax $0.1 \%$ ), while the lowest weight gain was in group 5 (AY $0.2 \%$ ) with $1933.10 \mathrm{~g}$.

The data of the slaughter and carcass parameters in the study are given in Table 6 . The effects of the treatments on the slaughter weight and abdominal fat weight of the broilers were insignificant $(\mathrm{P}>0.05)$, while the effect on the carcass weight and carcass yield was significant $(\mathrm{P}<0.05)$. Group 2 ranked first in terms of carcass weight and carcass yield. However, in terms of carcass weight, the difference was only between the 2nd group and the other groups. Carcass yields of the 2nd, 3rd, and 4th groups were higher $(\mathrm{P}<0.05)$ compared to the control and 5th groups. It was noteworthy that the group containing $0.1 \%$ Thepax ranked first in terms of both carcass weight and carcass yield. Accordingly, it can be said that $0.1 \%$ Thepax dose is the most appropriate in terms of carcass weight and carcass yield.

\section{Discussion}

In this study, $0.1 \%$ Thepax were found to be significant $(\mathrm{P}<0.05)$ only on body weight gain in respect to performance parameters according to $0.2 \%$ AY. Results of studies showing that baker's yeast increases live weight in broiler chickens (Yalçın et al., 1993; Nabila et al., 2017) and that yeast has a significant effect on live weight gain of broiler chickens (Santin et al., 2001; Suzer et al., 2015; Mohamed et al., 2015; Sun et al., 2019;) with the result of this study was not similar. In addition, the results of the study (Boostani et al., 2013) in which Thepax had a significant effect on the body weight gain of broilers were not similar to the results of this study.

In this study, the effect of treatments on feed intake was insignificant. This finding was not similar to the findings of the studies (Yalçın et al., 1993; Gao et al., 2008; Nabila et al., 2017) in which yeast increased feed consumption in broilers. However, the finding of this study were similar to the findings of the study (Zhang et al., 2005) that Saccharomyces cerevisiae supplementation did not affect the feed consumption of broiler chickens.

In this study, the effect of the treatments on the feed efficiency value was insignificant. The results of the study in which baker's yeast worsen the FCR value in broiler chickens (Yalçın et al., 1993) and the study finding that Thepax has a significant effect $(\mathrm{P}<0.05)$ on the FCR value of broilers (Boostani et al., 2013) with the findings of this study were not similar. The findings of the study in which the effect of different levels of yeast culture on the FCR value in broiler chickens were significant (Santin et al., 2001) were not similar to the finding of this study. It is thought that yeast, which has the feature of increasing water consumption, causes watery stool, and thus affects the FCR value in broiler chickens negatively.

In this study, $0.1 \%$ Thepax had an important effect $(\mathrm{P}<0.05)$ on carcass weight whereas $0.1 \%$ Thepax, $0.2 \%$ Thepax and $0.1 \%$ AY were increased $(\mathrm{P}<0.01)$ carcass yield. The findings of the study in which Thepax has a significant effect on the carcass weight and carcass yield of broilers (Boostani et al., 2013) and the finding of the study in which yeast affects the carcass weight of broilers (25) with the findings of this study were similar. On the other hand, the results of this study did not show similarities with the results of the study, in which they reported that the addition of yeast to the diet had no effect on the carcass weight and carcass yield of broilers (Rezaeipour et al., 2012). 
In this study, abdominal fat weights were not affected by the treatment $(\mathrm{P}>0.05)$. This result was not similar to the results of the study in which the addition of yeast affected the abdominal fat content of broilers $(\mathrm{P}<0.05)$ (Boostani et al., 2013; Mohamed et al., 2015).

In this study, the effect of the treatments on the mortality rate of the groups was insignificant $(\mathrm{P}>0.05)$. This result was similar to the result of the study (Silva et al., 2010) in which the effect of yeast addition on the mortality rate in broiler chickens was insignificant.

\section{Conclusion}

The diets containing yeast had no any adverse effect on the performance parameters of broiler chickens compared to the control group. It was observed that feeding with rations added $0.1 \%$ Thepax especially compared to the control groups had a higher effect on the carcass weight and carcass yield of broilers. The numerical amount of abdominal fat in the group containing $0.2 \%$ Thepax was the lowest.

In this study, it was observed that Thepax had a more pronounced effect only on the It is thought that this effect may have arisen from the inactive-stable feature of Thepax. Accordingly, it is possible to claim that it is more appropriate to prefer inactive-stable yeasts in the feeding of broilers.

Inactive-stable yeast (Thepax) may be more effective in feeding broilers than active yeast because it is more resistant to environmental and digestive conditions. Therefore, it is thought that it may be more beneficial to prefer inactive-stable yeasts in cases where ration changes are made more frequently and feeding time is necessarily extended.

\section{Disclosure}

No potential conflict of interest was reported by the authors.

\section{Acknowledgements}

This research article was derived from the corresponding author's master dissertation (No: 55448). This research did not receive any specific grant from funding agencies in the commercial, or not-forprofit sectors

\section{References}

Afsharmanesh M, Barani M, Silversides FG. 2010. Evaluation of wet-feeding wheat-based diets containing Saccharomyces cerevisiae to broiler chickens. British Poultry Science, 51(6): 776-783.

Anonymous. 1983. Based on the amino acid, mineral and vitamin content of Cerevisiae a typical analysis for Thepax, Dox-al Italia SpA, Via Mascagni, Sulbiate Superiore. Monza E Brianza, Italy.

Boostani A, Mahmoodian Fard HR, Ashayerizadeh A, Aminafshar M. 2013. Growth performance, carcass yield and intestinal microflora populations of broilers fed diets containing thepax and yogurt. Brazilian Journal of Poultry Science, 15(1): 1-6.
Brock TD, Smith DW, Madigan MT. 1984. Biology of Microorganisms, 4th edition. Prentice-Hall, Inc., Englewood Cliffs, NJ. 112 pp.

Elgün A, Ertugay Z. 1990. Tahıl İşleme Teknolojisi. Atatürk Üniv. Ziraat Fakültesi Yayın No:718. s: 273-283.

Fathi MM, Al-Mansour S, Al-Homidan A, Al-Khalaf A, AlDamegh M. 2012. Effect of yeast culture supplementation on carcass yield and humoral immune response of broiler chicks. Veterinary World, 5(11): 651-657.

Gao J, Zhang HJ, Yu SH, Wu AG, Yoon I, Quigley J, Gao YP, Qi GH. 2008. Effects of yeast culture in broiler diets on performance and immunomodulatory functions. Poultry Science, 87(7): 1377-1384.

Gong J, Forster RJ, James HY, Chambers R, Wheatcroft R, Sabour PM, Chen S. 2002. Molecular analysis of bacterial populations in the ileum of broiler chickens and comparison with bacteria in the cecum. FEMS Microbiology Ecology, 41(3): 171-179.

Hassanein MS, Soliman, NK. 2010. Effect of probiotic (Saccharomyces cerevisiae) adding to diets on intestinal microflora and performance of hy-line layers hens. Journal of American Science, 6(11): 159-169. ISSN: 1545-1003.

Köşker Ö. Çakmakçı L. 1985. Genel Mikrobiyoloji. Ankara Üniversitesi Ziraat Fakültesi Yayınları, 955, pp:94-95.

Kubena LF, Chen TC, Deaton JW, Reece FN. 1974. Factors influencing the quantity of abdominal fat in broilers. Poultry Science, 53(1): 974-978.

Martinez MJ, Roy S, Archuletta AB, Wentzell PD, Anna-Arriola SS, Rodriguez A L, Aragon AD, Quiñones GA, Allen C, Werner-Washburne M. 2004. Genomic analysis of stationaryphase and exit in Saccharomyces cerevisiae: gene expression and identification of novel essential genes. Molecular Biology of the Cell, 15(12): 5295-5305.

Mohamed EA, Talha EA, Mojahid AA, Dafaalla EM. 2015. Effect of dietary yeast (saccharomyces cerevisiae) supplementation on performance, carcass characteristics and some metabolic responses of broilers. Animal and Veterinary Sciences, 3(5-1): 5-10.

NRC (National Research Council). 1994. Nutrient Requirements of Poultry: Ninth Revised Edition, 1994. Washington, DC: The National Academies Press.

Nabila,M., Yaakub, H., Alimon, AR. and Samsudin, AA.2017. Mal. J. Anim. Sci. 20(2): 83-93.

Ogbuewu I, Okoro VM, Mbajiorgu EF, Mbajiorgu CA. 2019. Yeast (Saccharomyces cerevisiae) and its effect on production indices of livestock and poultry- a review. Com Clinic Path., 28(3): 669-677.

Reed G, Tilak W Nagodawithana. 1991. Yeast Technology. Second Edition. Library of Congress Catalog Card. No:90, 33144. ISBN 978-94-011-9771-7 (eBook).

Reed G. 2012. Yeast technology. Van Nostrand Reinhold: Springer Netherlands, 2end; 2012. 454 p.

Rezaeipour V, Fononi H, Irani M. 2012. Effects of dietary Lthreonine and Saccharomyces cerevisiae on performance, intestinal morphology and immune response of broiler chickens. South African Journal Of Animal Science, 42(3): 266-273.

Rose HJ, Harrison S. 1971. "The yeasts". Vol. 2. Physiology and Biochemistry of Yeasts. XIV + 571 S., 73 Abb., 39 Tab. London-New York Academic Press, N.Y. USA.

Salim H, Huque K, Kamaruddin K, Beg AH. 2018. Global restriction of using antibiotic growth promoters and alternative strategies in poultry production. Science Progress, 101 (1): 52-75.

Santin E, Mariorka A, Macari M, Grecco M, Sanchez JC. 2001. Performance and intestinal mucosa development in broiler chickens fed ration containing Saccharomyces cerevisiae cellwall. The Journal of Applied Poultry Research, 10 (3): 236-244. 
Silva VK, Da Silva JDT, Gravena RA, Gravena RA, Marques RH, Hada FH, De Moraes VMB. 2010. Yeast extract and prebiotic in pre-initial phase diet for broiler chickens raised under different temperatures. Revista Brasileira de Zootecnia, 39(1): 165-174.

Stanley VG, Ojo R, Woldesenbet S, Hutchinson DH, Kubena LF. 1993. The use of Saccharomyces cerevisiae to suppress the effects of aflatoxicosis in broiler chicks. Poultry Science, 72(10) :1867-1872.

Sun Z, Wang T, Demelash N, Zheng S, Zhao W, Chen X, Zhen Y, Qin G. 2019. Effect of yeast culture (Saccharomyces cerevisiae) on Broilers: A preliminary study on the effective components of yeast culture. Animals (Basel), 10(1): 68 .

Suzer B, Altinbas B, Seyidoglu N, Arican I, Orman A, Yildiz H, Yalcin M. 2015. The effects of supplemental saccharomyces cerevisiae and phytase on growth performances and plasma biochemical parameters of broiler chickens. Journal of The Faculty of Veterinary Medicine, 34(1,2): 15-23.
Thongsong B, Kalandakanond-Thongsong S, Chavananikul V. 2008. Effects of the additionof probiotic containing both bacteria and yeast or an antibiotic on performance parameters, mortality rate and antibiotic residue in broilers. The Thai Journal of Veterinary Medicine, 38(1): 17-26.

Vohra A, Syal, P, Madan A. 2016. Probiotic yeasts in livestock sector. Animal Feed Science and Technology, 219, 31-47.

Wang WW, Ren WL, Li Z, Yue YS, Guo YM. 2017. Effects of live yeast on immune responses and intestinal morphological structure in lipopolysaccharide-challenged broilers. Canadian Journal of Animal Science, 97(1): 136-144.

Yalçın S, Önol AG, Koçak D, Özcan İ. 1993. Ekmek mayasının broyler rasyonlarında protein kaynağı olarak kullanılması. Doğa- Tr. J. of Veterinary and Animal Sciences, 17(4): 305309.

Zhang AW, Lee BD, Lee KW, Song KB, An GH, Lee CH. 2005. Effect of graded levels of dietary Saccharomyces cerevisiae on growth performance and meat quality in broiler chickens. Asian-Australasian Journal of Animal Sciences, 18(5): 699703. 